\title{
Excretion in the urine of aminoacridine precipitable polyuronides (acid mucopolysaccharides) in patients with rheumatoid arthritis
}

\author{
T. BITTER*, P. Siegenthaler, T. DePREUX, ANd E. MARTIN \\ Policlinique Médicale Universitaire, Geneva, Switzerland
}

Raised excretions of connective tissue acid mucopolysaccharides (MPS) have been documented by precipitation with aliphatic cations (Scott, 1955, 1960 ) in a number of metabolic connective tissue diseases, including gargoylism (Dorfman and Lorincz 1957), certain forms of Morquio's disease (Zellweger, Ponseti, Pedrini, Stamler, and von Noorden, 1961), and Marfan's syndrome (Berenson and Dalferes, 1965), but no clear-cut results have been obtained in inflammatory connective tissue diseases. Di Ferrante (1957) and Kamikubo (1966) found that patients with rheumatoid arthritis tended to have raised urinary MPS determined by using aliphatic cations in single 24 -hr collections. Similar studies by other workers (Thompson and Castor, 1966; Delbrück, Grimme, and Wette, 1967; Kaye, Ward, and Rosevear, 1967) have suggested that increased excretions correlate with activity of joint disease. However the levels of precipitable urinary MPS from healthy individuals (Berenson and Dalferes, 1965; Delbrück and others, 1967) may be due, in part, to coprecipitation of large amounts of neutral sugar containing urinary mucins (Di Ferrante and Popenoe, 1958; Stidworthy, Ellis, and Gottschalk, 1963). Careful isolation of sulphated urinary polyuronides led Loewi (1959) to the conclusion that the majority of patients with rheumatoid arthritis excrete normal amounts of these substances and that the raised excretion found in a few was not correlated with disease activity. The clinical significance of such laboratory findings has remained obscure. The aim of the present paper is to reinvestigate the question, using precipitation by 9aminoacridine hydrochloride, a reagent which in a single precipitation appears to give a more quantitative recovery of sulphated compounds together with a product the purity of which (Muir, 1958) is comparable to that obtained by Loewi (1959).

\section{Description of series}

29 patients with definite classical rheumatoid arthritis (Ropes, Bennett, Cobb, Jacox, and Jessar, 1959) were investigated. Clinical joint involvement was assessed by the number of large joints found to be both warm and tender to the touch and by the number of tender and swollen reripheral joints. Disease activity was estimated by duration of morning stiffness, aspirin requirement, and erythrocyte sedimentation rate.

The patients were divided into two groups according to the absence (Group I: 23) or presence (Group II: 6) of signs of systemic involvement. Table I shows that both groups were closely comparable when judged by the extent and activity of joint disease, by the degree of joint erosion (Kellgren and Lawrence, 1957), and by the incidence and elevation of the rheumatoid factor titre (agglutination of sensitized sheep erythrocytes). The highest titres (in excess of $1: 448$ ) were observed in two patients of Group I. On the other hand, the erythrocyte sedimentation rate tended to be higher in Group II.

Group II comprised six patients: two men aged 54 and 65 years respectively and four women between the ages of 26 and 61 years. These patients suffered from various combinations of pyrexia with tachycardia (of unknown origin), severe weight loss (in excess of 25 per cent. of previously recorded weight), unexplained poorly healing skin ulcers, polyneuropathy, pericarditis, pleural effusion, and restrictive lung disease with increased pulmonary markings on standard chest $x$-ray film. Five of these patients had circulating rheumatoid factor (Table I); one 26-year-old woman with pyrexia of unknown origin and pericarditis (precordial rub and widespread S-T elevation on electrocardiogram) had no detectable gamma-M globulin on immunoelectrophoresis and no rheumatoid factor.

None of the patients with rheumatoid arthritis had demonstrable antinuclear antibodies nor any L.E.phenomenon when tested on three different occasions. None had clinically detectable renal disease. None had received corticosteroid therapy within 3 months of the present investigation. In ten patients the disease had

* Please address reprint requests to:

Th. Bitter, M.D., Ph.D., Associate Professor of Medicine, Centre Hospitalier Universitaire, Sherbrooke (Quebec), Canada Supported by a grant of the Commission Fédérale des Maladies Rhumatismales (Switzerland) 
Table I Selected clinical and laboratory findings in 29 patients with rheumatoid arthritis ${ }^{1}$

\begin{tabular}{|c|c|c|c|}
\hline Group & $\begin{array}{l}I \\
(23)\end{array}$ & $\begin{array}{l}I I \\
(6)\end{array}$ & $P^{2}$ \\
\hline $\begin{array}{l}\text { No. with systemic disease } \\
\text { No. 'untreated' with recent onset of disease } \\
\text { No. of involved small joints } \\
\text { No. of involved large joints } \\
\text { Severity of erosions }(x \text { rays of hands) } \\
\text { No. with rheumatoid factor } 1: 56 \\
\text { Reciprocal titre of rheumatoid factor } \\
\text { Erythrocyte sedimentation rate }(\mathrm{mm} . / \mathrm{Hg}) \\
\text { AAPP-excretion }\left(\mu \mathrm{g} \text {. uronic ac. } / \mathrm{m}^{2} . / 24 \mathrm{hrs}\right)\end{array}$ & $\begin{array}{c}0 \\
8 \\
6 \cdot 3 \\
2 \cdot 8 \\
1 \cdot 8 \\
10 \\
156 \cdot 8 \\
50 \cdot 5 \\
<2,80\end{array}$ & $\begin{array}{c}6 \\
2 \\
5 \cdot 7 \\
3 \cdot 1 \\
2 \cdot 2 \\
5 \\
230 \cdot 7 \\
76 \cdot 4 \\
\text { g. }\end{array}$ & $\begin{array}{l}<0.01 \\
>0.05 \\
>0.05 \\
>0.05 \\
>0.05 \\
>0.05\end{array}$ \\
\hline
\end{tabular}

${ }_{1}^{1}$ Given as mean values for the patients of the given group or as proportion of patients in their group (fraction).

2 By the $\chi^{2}$ test whenever applicable.

3 Mean number of joints found swollen and tender to touch.

- Mean number of joints found swollen and warmer than surrounding areas.

- Average rating according to Kellgren and Lawrence (1957).

first shown itself during the 4 months preceding the analyses and no treatment had been given other than tablets containing acetylsalicylic acid purchased by the patient without prescription and taken ad libitum for the relief of pain.

For the sake of comparison a further series of patients was also included in the present study (Table II): ten patients with systemic lupus erythematosus: two with progressive systemic sclerosis accompanied by prominent teleangiectasias, juxta-articular calcifications, and widespread involvement including cardiac and renal manifestations; ten with ankylosing spondylitis; and three single patients with various forms of inflammatory arthritis.

Table II Excretion in the urine of aminoacridine precipitable polyuronides in patients with rheumatoid arthritis, and other connective tissue diseases, and healthy controls

\begin{tabular}{|c|c|c|c|c|c|}
\hline Diagnosis & & No. of patients & Sex & $\begin{array}{l}\text { AAPP excretion }{ }^{1} \\
\text { Mean }\end{array}$ & Range \\
\hline \multirow{2}{*}{$\begin{array}{l}\text { Rheumatoid } \\
\text { arthritis } \\
\text { (29) }\end{array}$} & Group I & 23 & $\begin{array}{l}\text { Male } \\
\text { Female }\end{array}$ & $\begin{array}{l}2,270 \\
1,882\end{array}$ & $\begin{array}{l}1,252-2,782 \\
1,354-2,155\end{array}$ \\
\hline & Group II & 6 & $\begin{array}{l}\text { Male } \\
\text { Female }\end{array}$ & $\begin{array}{l}6,098 \\
3,982\end{array}$ & $\begin{array}{l}(3,323 ; 8,872) \\
3,140-5,790\end{array}$ \\
\hline \multirow[t]{6}{*}{$\begin{array}{l}\text { Other } \\
\text { diseases } \\
\text { (25) }\end{array}$} & $\begin{array}{l}\text { Systemic } \\
\text { lupus } \\
\text { erythematosus }\end{array}$ & 10 & Female & 3,614 & $2,586-6,250$ \\
\hline & $\begin{array}{l}\text { Progressive } \\
\text { systemic } \\
\text { sclerosis }\end{array}$ & 2 & Female & 2,675 & $(2,658 ; 2,692)$ \\
\hline & $\begin{array}{l}\text { Rheumatoid } \\
\text { arthritis } \\
\text { with } \\
\text { psoriasis }\end{array}$ & 1 & Male & - & $(2,690)$ \\
\hline & $\begin{array}{l}\text { Reiter's } \\
\text { disease }\end{array}$ & 1 & Male & - & $(2,020)$ \\
\hline & Brucellosis & 1 & $\overline{\text { Male }}$ & - & $(2,605)$ \\
\hline & $\begin{array}{l}\text { Ankylosing } \\
\text { spondylitis }\end{array}$ & 10 & $\begin{array}{l}\text { Males } \\
\text { Female }\end{array}$ & $\begin{array}{l}2,048 \\
1,753\end{array}$ & $\begin{array}{l}1,546-2,480 \\
1,616-1,890\end{array}$ \\
\hline \multicolumn{2}{|c|}{ Healthy controls } & 31 & $\begin{array}{l}\text { Males } \\
\text { Females }\end{array}$ & $\begin{array}{l}2,494 \\
2,064\end{array}$ & $\begin{array}{l}2,227-2,643 \\
1,892-2,320\end{array}$ \\
\hline
\end{tabular}

\footnotetext{
$1 \mu \mathrm{g}$. uronic acid $/ \mathrm{m}^{2} . / 24 \mathrm{hrs}$ (Isolated values recorded in brackets).
} 


\section{Method and material}

Urine was collected at $+4^{\circ} \mathrm{C}$. over thymol for three separate 24 -hr periods and, to minimize seasonal variations, all specimens were collected between February 1 and April 30. In pre-menopausal females collections were carried out during the 4 days after the last day of the period. Daily creatinine output was determined and any collection was discarded and repeated if one value fell outside the \pm 10 per cent. range. Non-dialysable 9-aminoacridine-precipitable polyuronides (AAPP) were isolated by a technician from duplicate aliquots of the pooled 72-hr collection labelled by number only, without knowledge of the diagnosis. The isolation procedure was modified from that described by Muir (1958) as outlined in Table III.

Soluble salts of polyuronides were obtained from their aminoacridire precipitate in the following manner: 20 parts $(v: v)$ of cation exchange resin (Table III) were added to the precipitate together with $2 \mathrm{ml}$. saturated aqueous sodium acetate adjusted to $\mathrm{pH} 8 \cdot 0$, stirring the mixture intermittently for $15 \mathrm{~min}$. at room temperature with a glass rod. This suspension was then poured into individual siliconed glass columns $(120 \times 5 \mathrm{~mm}$.); their tapered tips, packed with acid-washed, well-rinsed glass wool, drained into $10 \mathrm{ml}$. volumetric flasks. $2 \mathrm{ml}$. aliquots of $0.58 \mathrm{~N} \mathrm{NaCl}$ (c.f. Tamm and Horsfall, 1950) were used sequentially to wash the glass rod and the wall of the centrifuge tube, and then to elute the remainder of MPS from the resin-filled column up to the $(10.0 \mathrm{ml}$.) mark of the flask. A final such wash $(2.0 \mathrm{ml}$.) was checked for absence of detectable hexuronic acid.

Amounts of extracted polyuronides were assessed by determination of the total hexuronic acid (Bitter and Muir, 1962) in the MPS-solution collected in volumetric flasks and expressed as $\mu \mathrm{g}$. uronic acid/24 hr/sq. m. total body surface (Crawford, Terry, and Rourke, 1950). Duplication errors of the entire isolation never exceeded \pm 6.0 per cent., but were usually found below \pm 3.0 per cent.

\section{Results}

These are given in Figs 1 and 2, and in Table II.

\section{Healthy individuals}

AAPP excretions were found to vary little from one individual to another. The mean for adult males was $2,494 / \mu \mathrm{g}$. uronic acid per $24 \mathrm{hrs}$ per sq. m. (with a standard deviation (S.D.) of $160 / \mu \mathrm{g} . / 24 \mathrm{hrs} / \mathrm{m}^{2}$.) and for adult females $2,064 / \mu \mathrm{g} . / 24 \mathrm{hrs} / \mathrm{m}^{2}$. (S.D. = $59 / \mu \mathrm{g} . / 24 \mathrm{hrs} / \mathrm{m}^{2}$.).

However two women above the age of 62 years and two men above 67 years had AAPP excretions which were several hundred $\mu \mathrm{g}$. below the respective means and were recorded separately (Fig. 1).

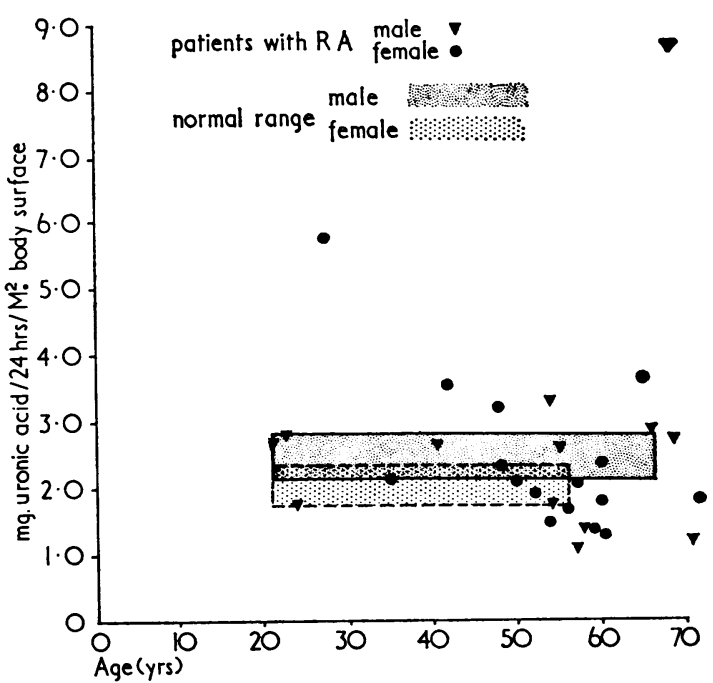

FIG. 1 Excretion of uronic acid in patients with rheumatoid arthritis.

Table III Isolation of aminoacridine-precipitable polyuronides from urine. Flow chart

POOLED (72-hr) URINE COLLECTIONS (150 ml. aliquot)

DIALYSED UURINE

$(2 \times 60.0 \mathrm{ml}$. samples $)$

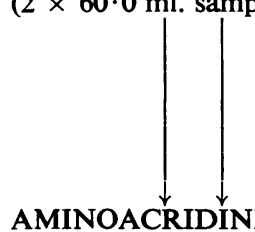

Dialysis

(72 hrs against deionized toluene-covered $\mathrm{H}_{2} \mathrm{O}$, in preheated ${ }^{1}$ tubing) Dialysate cleared by centrifugation $(27,000 / \mathrm{G}$., $30 \mathrm{~min}$.) POLYURONIDES

\section{Isolation of MPS}

pH Adjusted to 3.5 with $N / 10 \mathrm{HCl}$

Precipitation by 9 -aminoacridine. $\mathrm{HCl}(30 \mathrm{ml}$. per sample of a saturated $\left(+56^{\circ} \mathrm{C} . ; 1.5\right.$ per cent.) aqueous solution)

Storage at $+4^{\circ} \mathrm{C}$. for $96 \mathrm{hrs}$

Displacement of reagents in presence of $2 \mathrm{~N} \mathrm{Na-acetate} \mathrm{pH} 8$ and 'Zeokarb 225'2

(Expressed as $\mu \mathrm{g}$. hexuronic $\mathrm{acid}^{3} / \mathrm{m}^{2} . / 24 \mathrm{hrs}$ )

1 'Visking' cellulose tubing $20 / 32$ ', heated at $+95^{\circ} \mathrm{C}$. in a dry oven for $72 \mathrm{hrs}$. as the Permutit Co., London, W.4. (or 'Dowex-50') $\mathrm{Na}^{+}$form, 8 per cent. cross-linked, 200-400 mesh, washed as in Muir (1958), handled

3 Method of Bitter and Muir (1962). 
Group 1 (23 patients with uncomplicated rheumatoid arthritis).

Normal or below-normal AAPP excretions were found. Excretions at the upper limit of normal (when defined by two S.D. from the mean) were seen in:

(1) A 64-year-old patient with an unrelenting factor negative rheumatoid arthritis (without distal interphalangeal involvement), an erythrocyte sedimentation rate of $100 \mathrm{~mm}$./1 st $\mathrm{hr}$, and mild psoriasis;

(2) A 21-year-old patient with recent onset of a febrile extensive rheumatoid arthritis accompanied by prominent tenosynovitis but no systemic manifestations;

(3) A 20-year-old butcher with monoarthritis of one knee and sacroiliitis during the course of a brucellosis with orchitis.

Group II (6 patients with rheumatoid arthritis and systemic involvement.)

Raised AAPP excretions up to four times the normal were found in all patients. (Fig. 1).

Systemic lupus erythematosus (10) and progressive systemic sclerosis (2).

These patients were found to excrete raised amounts of AAPP. The two patients with progressive systemic sclerosis and three steroid-treated patients with lupus erythematosus had only minor elevation of excretion above the 2 S.D. limit. The highest elevations amongst the lupus patients were seen in four women without clinically demonstrable renal disease who had not had treatment with steroids (Fig. 2).

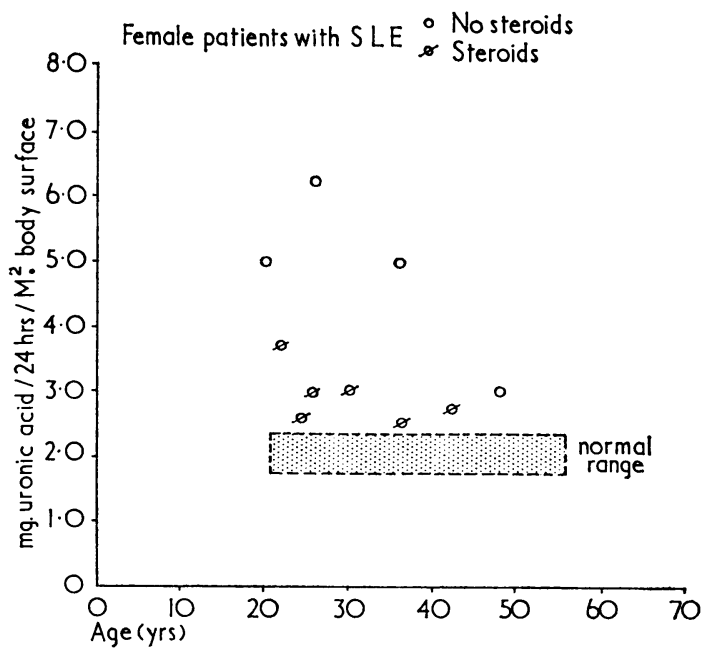

FIg. 2 Excretion of uronic acid in female patients with systemic lupus erythematosus.
Ankylosing spondylitis (10)

These patients showed normal or below-normal AAPP excretions (Thompson and Castor, 1966).

\section{Discussion}

In view of their rapid turnover (Schiller, Mathews, Cifonelli, and Dorfman, 1956), acid mucopolysaccharides have been considered with reason to be the most vulnerable of extracellular tissue components and thus might well be affected by widespread inflammatory connective tissue disease. Increased degradation of hyaluronic acid resulting in decreased concentration and partial degradation of this polyuronide has been observed in the synovial fluid of patients with rheumatoid arthritis (Johnston, 1955), a phenomenon which could well be a by-product of many chronic granulomatous inflammations with liberation of lysosomal hydrolases. In fact conspicuously metachromatic lesions are seen in some connective tissue diseases, such as fibrinoid necrosis (Altshuler and Angevine, 1949) and amyloidosis (Bitter and Muir, 1966), and MPS turnover and degradation has been postulated (Hauss, JungeHülsing, and König, 1962). Just as higher turnover of soluble collagen seems to be related to increased excretion of hydroxyproline in urine, so one might expect enhanced MPS turnover to be reflected in raised renal output of polyuronides or fragments thereof.

Technical difficulties in MPS determination in urine have been referred to above (Berenson and Dalferes, 1965). They appear to arise chiefly from the following:

The polydispersion of urinary MPS (Berggard, 1961; King, Fielden, and Boyce, 1962; Kelley Poncet, and Di Ferrante, 1963; Varadi, Cifonelli, and Dorfman, 1967; Muir, 1964) may lead to incomplete precipitation and recovery (Kaplan and Meyer, 1962), or on the other hand to a more than 10-fold excess of (partially anionic) urinary glycoproteins and mucins (Tamm and Horsfall, 1950; Di Ferrante and Popenoe, 1958; Berggård 1961; King and others, 1962; Stidworthy and others, 1963) which interfere, as impurities, with hexosamine and uronic acid determinations. Cationic quaternary ammonium detergents (Scott, 1955; 1960) are invaluable tools for the isolation and analysis of essentially undegraded MPS extracted from tissues. However, when applied to the assessment of subtle variations in the urinary excretion of these substances, including variations due to age (Kao, Hizer, and McGavack, 1967; Teller and Krüger, 1967), sex (Di Ferrante and Rich, 1956; Loewi, 1959; Thompson and Castor, 1966), or inflammatory connective tissue disease (Di Ferrante, 1957; Di Ferrante, Robbins, and Rich, 1957; Øhlenschlaeger and Friman, 1968), this approach has 
led to inconsistent results and has discouraged clinicians from its regular use.

9-Aminoacridine hydrochloride was selected by Egami (1939) and Dodgson, Rose, and Spencer (1955) for the quantitative recovery of molecules as small as glucose sulphate. Moreover, when used at $\mathrm{pH} 3 \cdot 5$, coprecipitation of anthrone-positive mucins was reduced to barely detectable amounts. Also, at this $\mathrm{pH}$, aminoacridine precipitates sulphated MPS with a reasonable degree of selectivity, leaving 75 per cent. of non-sulphated MPS and even macromolecular umbilical cord hyaluronic acid in solution (Bitter and Muir, 1963). Although hyaluronic acid contributes little to normal polyuronides of urine (Kelley and others, 1963; Kao and others, 1967; Varadi and others, 1967), the concentration in urine of non-sulphated or de-sulphated MPS might well vary within wide limits and explain some of the scatter of normal values obtained by precipitation with aliphatic cations. Thus precipitation of essentially sulphated polyuronides by aminoacridine at $\mathrm{pH} 3.5$ appears to afford an approach analogous to, though more quantitative than, that used by Loewi (1959) and might explain the somewhat similar results obtained.

Yet in one aspect the results were surprising. A normal AAPP excretion was observed in a number of patients with florid, highly erosive rheumatoid arthritis, in contrast to markedly raised excretions in patients with systemic lupus erythematosus (c.f. Di Ferrante and others, 1957) and progressive systemic sclerosis who were suffering from more severe arthralgias. Hence it would appear that the sulphated polyuronides ecxreted in excess by the latter as well as by patients with systemic rheumatoid disease originated not in joints but rather in visceral connective tissues, possibly in vessel walls. If indeed involved vessel walls were responsible for AAPP excreted in excess, the latter might well turn out to be typical vessel wall MPS such as heparan (Muir, 1965) or dermatan sulphates, which are present in normal urine in trace amounts only (King and others, 1962; Kelley and others, 1963; Berensen and Dalferes, 1965; Varadi and others, 1967). In fact, circulating protamine-precipitable anticoagulants have been described in some patients with systemic lupus erythematosus (Thiers, Favre-Gilly, Fayolle, Colomb, Chassard, and Thouverez, 1958).

Clearly, more work is needed if the corre'ation suggested by the present data is to be confirmed: one would expect, for example, that the same minority of patients with rheumatoid disease and abnormal AAPP excretion would show altered digital artery design (Scott, El Sallab, and Laws, 1967) or vasculitis on rectal biopsy (Schneider and Dobbins, 1968).

\section{Summary}

Excretion in the urine of aminoacridine precipitable polyuronides was determined in 29 adult patients with rheumatoid arthritis, 31 adult controls, and 26 individuals affected by various connective tissue diseases, notably ten patients with systemic lupus erythematosus. Except for the last named, only six of the patients with rheumatoid arthritis showed a raised excretion up to 4-fold of such polyuronides. This finding did not correlate with the severity or extent of the arthritis, nor with the titre of rheumatoid factor, whenever present. Although neither L.E. phenomenon nor antinuclear antibodies could be demonstrated in these six patients, their visceral and systemic involvement was conspicuous, not unlike that of the patients with systemic lupus erythematosus and equally raised aminoacridine precipitable polyuronides.

\section{References}

Altshuler, C. H., And Angevine, D. M. (1949) Amer. J. Path., 25, 1061 (Histochemical studies on the pathogenesis of fibrinoid).

Berenson, G. S., AND Dalferes, E. R. (1965) Biochim. biophys. Acta, 101, 183 (Urinary excretion of mucopolysaccharides in normal individuals and in Marfan's syndrome).

BERGGÅRD, I. (1961) Ark. Kemi., 18, 291 (Proteins, glycoproteins and mucopolysaccharides in normal human urine. I. Fractionation of non-dialyzable materials by ultrafiltration and by zone electrophoresis).

Bitter, T., AND MuIr, H. M. (1962) Anal. Biochem., 4, 330 (A modified uronic acid carbazole reaction).

- - (1963) Unpublished observations.

(1966) J. clin. Invest. 4, 963 (Mucopolysaccharides of whole human spleens in generalized amyloidosis).

Crawford, J. D., Terry, M. E., ANd Rourke, G. M. (1950) Pediatrics, 5, 783 (Simplification of drug dosage calculation by application of the surface area principle). 
Delbrück, A., Grimme, H., AND Wette, K. (1967) Z. klin. Chem., 5, 10 (Zur Ausscheidung saurer Mucopolysaccharide im Harn).

Di Ferrante, N. (1957) J. clin. Invest., 36, 1516 (Urinary excretion of acid mucopolysaccharides by patients with rheumatoid arthritis).

_ AND Popenoe, E. A. (1958) Scand. J. clin. Lab. Invest., 10, Suppl. 31, p. 268 (Hexosamine containing proteins co-precipitated with urinary mucopolysaccharides).

— AND Rich, C. (1956) J. Lab. clin. Med., 48, 491 (The determination of acid mucopolysaccharides in urine). , RobBins, W. C., AND RICH, C. (1957) Ibid., 50, 897 (Urinary excretion of acid mucopolysaccharides by patients with lupus erythematosus).

Dodgson, K. S., Rose, F. A, ANd Spencer, B. (1955) Biochem. J., 60, 346 (Studies on the sulphatases. 10. The isolation and characterization of biosynthetic arylsulphates).

Dorfman, A., AND Lorincz, H. E. (1957) Proc. nat. Acad. Sci., 43, 443 (Occurrence of urinary acid mucopolysaccharides in the Hurler syndrome).

Egami, F. (1939) J. chem. Soc. Japan, 60, 853 (Sulfatase models. III. Precipitation reaction of some sulphuric acid esters with tripaflavine, rivanol, etc) [In Japanese[.

Hauss, W. H., Junge-Hülsing, G., AND KöNIG, F. (1962) Med. Welt, p. 2371 (Über das Vorkommen von Veränderungen des Mucopolysaccharidstoffwechsels in der Klinik).

Johnston, J. P. (1955) Biochem. J., 59, 633 (The viscosity of normal and pathological human synovial fluids).

Kamikubo, K. (1966) Acta paediat. Jap., 70, 302 (Studies on acid mucopolysaccharides in the urine. II. In collagen diseases) [In Japanese].

Kao, K. Y. T., Hizer, C. H., and McGavack, T. H. (1967) Proc. Soc. exp. Biol. (N.Y.), 125, 1040 (Urinary protein and carbohydrate. III. Age differences in acid mucopolysaccharides in human beings).

KAPLAN, D., AND MeYer, K. (1962) J. clin. Invest., 41, 743 (The fate of injected mucopolysaccharides).

KAYE, R. L., WARD, L. E., AND Rosevear, J. V. (1967) Arthr. and Rheum., 10, 289 (Urinary acid mucopolysaccharides as a measure of activity in rheumatoid arthritis.-Abstr.-).

Kellgren, J. H., And Lawrence, J. S. (1957) Ann. rheum. Dis., 16, 485 (Radiological assessment of rheumatoid arthritis).

Kelley, W. R., Poncet, I. B., AND Di Ferrante, N. (1963) Nature (Lond.), 197, 1204 (Heterogeneity of urinary acid mucopolysaccharides).

King, J. S., Fielden, M. L. AND Boyce, W. H. (1962) Clin. chim. Acta, 7, 316 (Acid mucopolysaccharides in normal urine).

LOEWI, G. (1959) Ann. rheum. Dis., 18, 239 (Urinary excretion of acid mucopolysaccharides in rheumatoid arthritis and other diseases).

MUIR, H. (1958) Biochem. J., 69, 195 (The nature of the link between protein and carbohydrate of a chondroitin sulphate complex from hyaline cartilage).

- (1964) In 'International Review of Connective Tissue Research', ed. D. A. Hall, vol. 2, p. 140. Academic Press, New York and London. (1965) In 'Structure and Function of Connective and Skeletal Tissue', ed. S. F. Jackson, R. D. Harkness, S. M. Partridge, and G. R. Tristram, p. 137. Butterworths, London.

ØhlensChlaeger, K., AND Friman, C. (1968) Scand. J. Lab. Invest., 21, 364 (Anormal urinary excretion of acid mucopolysaccharides in generalized scleroderma).

Ropes, M. W., Bennett, G. A., Cobb, S., Jacox, R. F., and Jessar, R. A. (1959) Ann. rheum. Dis., 18, 49 (1958 Revision of diagnostic criteria for rheumatoid arthritis).

Schiller, S., Mathews, M. B., Cifonelli, J. A., And Dorfman, A. (1956) J. biol. Chem., 218, 139 (The metabolism of mucopolysaccharides in animals. III. Further studies on skin utilizing $\mathrm{C}^{14}$ glucose, $\mathbf{C}^{14}$-acetate, and $\mathbf{S}^{\mathbf{3 5}}$-sodium sulfate).

SChNeider, R. E., AND Dobins, W. D. (1968) Ann. intern. Med., 68, 561 (Suction biopsy of the rectal mucosa for diagnosis of arteritis in rheumatoid arthritis and related diseases).

Scotr, J. E. (1955) Chemistry and Industry (Lond.), p. 168 (Reaction of long-chain quaternary ammonium salts with acidic polysaccharides). (1960) Methods biochem. Anal., 8, 145 (Aliphatic ammonium salts in the assay of acidic polysaccharides from tissues).

Scott, J. T., El Sallab, R. A., AND Laws, J. W. (1967) Brit. J. Radiol., 40, 748 (The digital artery design in rheumatoid arthritis-further observations).

Stidworthy, G. H., Ellis, P. J., AND GotrschalK, R. G. (1963) Proc. Soc. exp. Biol (N. Y.), 112, 864 (Separation of sulfated urinary mucopolysaccharides using cetyltrimethylammonium bromide and ethyl alcohol).

TAMm, I., AND HoRSfall, F. L. (1950) Ibid., 74108 (Characterization and separation of an inhibitor of viral hemagglutination present in urine). 
Thiers, H., Favre-Gilly, J., Fayolle, J., Colomb, D., Chassard, A., and Thouverez, J. P. (1958) Lyon méd., 200, 961, 981 (Purpura hémorrhagique mortel avec héparinémie au cours d'une lupo-érythémato-viscérite).

Thompson, G. R. ANd CASToR, C. W. (1966) J. Lab. clin. Med., 68, 617 (Excretion of non-dialyzable urinary mucopolysacchride in rheumatic and other systemic disease states).

Teller, W., AND KRüger, C. (1967) Experientia (Basel), 23, 908 (Age-dependent changes of acid mucopolysaccharide excretion patterns in human urine).

Varadi D. P., Cifonelli, J. A., And Dorfman, A. (967) Biochim. biophys. Acta, 141, 103 (The acid mucopolysaccharides in normal urine).

Zellweger, H., Ponseti, I. V., Pedrini, V., Stamler, F. S., and von Noorden, G. K. (1961) J. Pediat., 59, 549 (Morquio-Ullrich's disease. Report of two cases). 